\title{
PERLINDUNGAN HUKUM BAGI KREDITOR YANG BERITIKAD BAIK AKIBAT PEMBATALAN HAK TANGGUNGAN
}

\author{
Lilawati Ginting \\ Fakultas Hukum Universitas Muhammadiyah Sumatera Utara \\ Email: lilawati.ginting@gmail.com
}

\begin{abstract}
Security rights aims for giving protection and legal certainty for stakeholders, which one it is dependent creditor rights holders, but in practice this goal still cannot fully carried out, due to ongoing security rights can still be canceled court. Debitors must still be my response if the object binding guarantee with the court canceled encumbrance, such as spending manifestly been issued by the creditors, and for loss of expected profit from lending. Other efforts to do creditor to restore the rights of Its preferred to debtors, namely by requiring the debtor to replace a security object that has been canceled court with other objects which have a face value equal, and then do the loading objects according to new guarantee, such as in the form of a security interest, fiduciary, mortgages or liens.
\end{abstract}

Kata Kunci: Hak Tanggungan, Kreditor, Debitor.

\section{A. Latar Belakang}

Bank adalah lembaga keuangan yang kegiatan operasionalnya berada dalam lingkup usaha menghimpun dana dari masyarakat dan mengelola dana dengan menanamnya kembali kepada masyarakat (dalam bentuk pemberian kredit) sampai dana tersebut kembali lagi ke bank (Hasanudin Rahman 1995: 9). Dalam pemberian kredit, ada beberapa hal yang harus diperhatikan oleh bank sebagai kreditor, dalam rangka melindungi dan mengamankan dana masyarakat yang dikelola oleh bank tersebut untuk disalurkan dalam bentuk kredit kepada debitor.

Pengamanan kepada kreditor dalam menyalurkan kredit kepada debitor tersebut salah satunya adalah melalui perjanjian jaminan yang diadakan antara bank dan debitor. Mengenai penjaminan, dalam hukum positif Indonesia terdapat berbagai bentuk peraturan perundang undangan yang mengatur atau berkaitan dengan jaminan yang disebut sebagai hukum jaminan, yang berlaku sebagai 
ketentuan yang bertujuan melindungi pihak pihak yang berkepentingan ( $M$. Bahsan 2007: 102).

Adapun kegunaan dari penjaminan dalam pemberian kredit perbankan dapat diuraikan sebagai berikut (Rachmadi Usman 2008: 71):

1. memberikan hak dan kekuasaan kepada kreditor untuk mendapatkan pelunasan dari agunan apabila debitor melakukan cidera janji, yaitu untuk membayar hutangnya kembali pada waktu yang telah ditetapkan dalam perjanjian;

2. menjamin agar debitor berperan serta dalam transaksi untuk membiayai usahanya, sehingga kemungkinan untuk meninggalkan usahanya atau proyeknya dengan merugikan diri sendiri atau perusahaannya, dapat dicegah atau sekurang-kurangnya kemungkinan untuk berbuat demikian dapat diperkecil; dan

3. memberikan dorongan kepada debitor untuk memenuhi janjinya, khususnya mengenai pembayaran kembali sesuai dengan syarat-syarat yang telah disetujui agar debitor dan/atau pihak ketiga yang ikut menjamin tidak kehilangan kekayaan yang telah dijaminkan.

Permintaan jaminan oleh bank dalam penyaluran kredit tersebut merupakan realisasi dari prinsip kehati-hatian bank sebagaimana ditentukan UU Perbankan. Pasal 8 ayat 1 Undang-undang Nomor 10 Tahun 1998 tentang Perbankan menyebutkan (Hermansyah 2008: 72-73):

Dalam memberikan kredit atau pembiayaan berdasarkan Prinsip Syariah, Bank Umum wajib mempunyai keyakinan berdasarkan analisis yang mendalam atau itikad baik dan kemampuan serta kesanggupan Nasabah Debitur untuk melunasi utangnya atau mengembalikan pembiayaan dimaksud sesuai dengan yang diperjanjikan.

Jaminan yang banyak diminta oleh bank adalah jaminan berupa hak atas tanah karena didasarkan pada pertimbangan bahwa tanah pada umumnya mudah dijual, harganya terus meningkat, mempunyai tanda bukti hak, sulit digelapkan dan dapat dibebani dengan hak tanggungan yang memberikan hak istimewa kepada kreditor (Adrian Sutedi 2010: 7). Pasal 1 angka 1 Undang-undang Nomor 4 Tahun 1996 tentang Hak Tanggungan atas Tanah Beserta Benda-benda yang 
Berkaitan dengan Tanah, menyebutkan: (Kartini Muljadi dan Gunawan Widjaja 2004: 13):

Hak tanggungan atas tanah beserta benda-benda yang berkaitan dengan tanah, yang selanjutnya disebut hak tanggungan adalah hak jaminan yang dibebankan pada hak atas tanah sebagaimana dimaksud dalam Undangundang Nomor 5 Tahun 1960 tentang Peraturan Dasar Pokok-pokok Agraria, berikut atau tidak berikut benda-benda lain yang merupakan satukesatuan dengan tanah itu, untuk pelunasan utang tertentu, yang memberikan kedudukan yang diutamakan kepada kreditor tertentu terhadap kreditor-kreditor lain.

Melalui pengertian tersebut di atas dapat dilihat unsur-unsur yang tercantum dalam pengertian hak tanggungan, yaitu (Salim H.S. 2004: 96-97):

1. hak jaminan yang dibebankan pada hak atas tanah, yakni adanya hak penguasaan yang secara khusus dapat diberikan kepada kreditor sehingga apabila debitor cidera janji maka kreditor memiliki wewenang untuk menjual tanah yang dijadikan objek jaminan untuk pelunasan atas hutang-hutang debitor;

2. hak atas tanah berikut atau tidak berikut benda-benda lain yang merupakan suatu kesatuan dengan tanah itu, yakni bahwa objek yang dibebani hak tanggungan adalah dapat berupa hak atas tanah semata-mata, atau juga hak atas tanah berikut dengan benda-benda yang ada di atasnya;

3. untuk pelunasan hutang tertentu, yakni bahwa hak tanggungan dimaksudkan untuk menyelesaikan hutang-hutang debitor yang ada pada kreditor, dan disini tampak sifat accessoir dari perikatan jaminan hak tanggungan, dimana hak tanggungan baru ada setelah adanya perikatan kredit;

4. memberi kedudukan yang diutamakan kepada kreditor tertentu terhadap kreditor-kreditor lainnya, yakni bahwa apabila dilakukan eksekusi terhadap objek jaminan maka kreditor pemegang hak tanggungan memiliki posisi yang didahulukan dalam mengambil pelunasan atas piutangnya dari hasil eksekusi objek yang dijaminkan.

Berdasarkan unsur-unsur yang terkandung dalam pengertian hak tanggungan dapat dilihat bahwa undang-undang hak tanggungan memberikan perlindungan hukum kepada kreditor pemegang hak tanggungan, perlindungan hukum terhadap kreditor pemegang hak tanggungan juga dapat dilihat dalam Penjelasan Umum Undang-undang Hak tanggungan, yang menyebutkan tentang ciri-ciri dari hak tanggungan sebagai lembaga hak jaminan atas tanah yang kuat yaitu (A.P. Parlindungan, 1996: 282):

1. memberikan kedudukan yang diutamakan atau mendahulu kepada pemegangnya (droit de preference); 
2. selalu mengikuti obyek yang dijaminkan dalam tangan siapapun obyek itu berada (droit de suite);

3. memenuhi asas spesialitas dan asas publisitas, sehingga dapat mengikat pihak ketiga dan memberi kepastian hukum kepada pihak-pihak yang berkepentingan, dan

4. mudah dan pasti pelaksanaan eksekusinya.

Agar perlindungan hukum bagi kreditor pemegang hak tanggungan dapat dicapai maka pembebanan hak tanggungan harus memenuhi persyaratan dan dilakukan sesuai dengan ketentuan hukum yang berlaku. Pelaksanaan pembebanan hak tanggungan dilaksanakan melalui dua tahap kegiatan, yaitu tahap pemberian hak tanggungan yang dilakukan dengan perjanjian tertulis, yang dituangkan dalam Akta Pemberian Hak tanggungan (APHT) di hadapan Pejabat Pembuat Akta Tanah dan tahap dilakukannya pendaftaran hak tanggungan di Kantor Pertanahan (Rachmadi Usman 2008: 397-401), karena pada dasarnya pemberian hak tanggungan hanya dimungkinkan jika dibuat dalam bentuk perjanjian, maka pemberian hak tanggungan tersebut harus memenuhi syarat sahnya perjanjian seperti yang ditentukan dalam Pasal 1320 KUH Perdata, dan salah satu syaratnya adalah kecakapan untuk membuat suatu perikatan.

Kecakapan bertindak dalam banyak hal berhubungan dengan masalah kewenangan bertindak dalam hukum, dimana kecakapan berkaitan dengan masalah kemampuan untuk melakukan suatu tindakan/perbuatan hukum dan kewenangan berkaitan dengan kapasitas subjek hukum dalam melakukan tindakan/perbuatan hukum (Kartini Muljadi dan Gunawan Widjaja 2004: 52). Perjanjian hak tanggungan kewenangan menentukan pemberi hak tanggungan berkaitan dengan kewenangan untuk melakukan perbuatan hukum atas objek hak tanggungan, karena pemberi hak tanggungan adalah pemilik persil yang dengan sepakatnya dibebani dengan hak tanggungan sampai sejumlah hutang tertentu untuk menjamin suatu perikatan/hutang (J. Satrio 1997: 245), sehingga yang dapat menjadi pemberi hak tanggungan adalah pemilik hak atas tanah yang dijaminkan.

Kewenangan pemberi hak tanggungan tersebut sangat penting untuk diperhatikan karena apabila pemberian objek hak tanggungan tidak dilakukan oleh pemiliknya, maka pemberian objek jaminan tersebut dapat menjadi batal dan 
selanjutnya atas akta pembebanannya juga menjadi batal demi hukum (Try Widiyono 2009: 290).

Apabila terjadi pembatalan hak tanggungan maka tujuan untuk memberikan perlindungan hukum bagi kreditor pemegang hak tanggungan tidak akan tercapai, tetapi dalam praktik untuk memastikan pemilik yang sah dari suatu hak atas tanah terkadang sulit, hal ini dikarenakan pendaftaran hak atas tanah yang dianut Indonesia berdasarkan PP No.24 Tahun 1997 tentang Pendaftaran Tanah menggunakan sistem publikasi negatif yang mengandung unsur positif. Hal ini berarti sertifikat sebagai tanda bukti yang kuat atas kepemilikan suatu hak atas tanah akan tetapi tidak mutlak, sehingga pemilik terdaftar masih dapat digugat oleh orang lain yang merasa berhak (Adrian Sutedi 2010: 120-122).

Berkenaan dengan hak tanggungan maka apabila ada gugatan dari pihak ketiga untuk membatalkan sertifikat hak atas tanah yang sedang dijadikan objek jaminan oleh debitor,dan kemudian atas gugatan itu oleh Pengadilan diputuskan bahwa pihak ketiga yang menggugat menjadi pemilik sah atas sertifikat hak atas tanah tersebut akan mengakibatkan hak debitor terhadap objek jaminan menjadi hapus, dimana hapusnya hak debitor terhadap objek jaminan akan mengakibatkan hapusnya hak tanggungan yang sedang berjalan.

Keadaan demikian tentu dapat merugikan kreditor pemegang hak tanggungan, sebab hapusnya hak tanggungan yang sedang berjalan akan mengakibatkan kreditor pemegang hak tanggungan akan kehilangan objek jaminan atas piutangnya kepada debitor. Padahal jika merujuk pada yurisprudensi yakni Putusan Mahkamah Agung Republik Indonesia No.: 251 K/Sip/1958 Tanggal 26 Desember 1958 yang pada pokoknya menentukan bahwa "pembeli yang telah bertindak dengan itikad baik harus dilindungi dan jual beli yang bersangkutan harus dinyatakan sah", seharusnya kreditor yang dalam menerima penjaminan telah bertindak sesuai ketentuan yang berlaku dapat disebut sebagai pihak yang beritikad baik, dan karena itu harus dilindungi haknya. Dalam gugatan-gugatan yang menyangkut tentang hak tanggungan, sering sekali Hakim memutuskan untuk membatalkan pembebanan hak tanggungan yang sedang dipegang oleh kreditor. Hal tersebut mengakibatkan kepastian dan perlindungan 
hukum bagi para pihak yang ada dalam jaminan hak tanggungan yang dalam penelitian adalah kreditor pemegang hak tanggungan tidak tercapai.

\section{B. Metode Penelitian}

Jenis penelitian hukum dapat dibedakan menjadi penelitian hukum normatif dan penelitian hukum empiris/sosiologis. Penelitian hukum normatif merupakan penelitian yang datanya bersumber pada data sekunder dan berhubung data penelitian ini adalah data sekunder, maka termasuk dalam jenis penelitian hukum normatif. Sifat penelitian ini adalah deskriptif, yang bertujuan untuk memberikan gambaran tentang gejala-gejala sosial yang terkait dengan kepastian hukum bagi kreditor yang beritikad baik atas hak tanggungan yang perjanjiannya dibatalkan. Sumber data penelitian berupa bahan hukum primer, bahan hukum sekunder dan bahan hukum tersier. Metode pengumpulan data dilakukan menggunakan teknik studi dokumen, yang dianalisis dengan menggunakan teknik analisis kualitatif.

\section{Hasil Penelitian dan Analisis}

\section{Kajian teoritis terhadap hak tanggungan}

Dalam penelitian ini teori digunakan untuk memecahkan masalah, adapun teori yang dipergunakan adalah teori perlindungan hukum, teori pertanggungjawaban dan teori hukum jaminan kebendaan. Teori perlindungan hukum mengandung teori yang berkaitan dengan perlindungan subjek hukum sebagai pendukung hak dan kewajiban dalam pemberian kredit dengan jaminan hak tanggungan. Menurut Van Kan "hukum adalah keseluruhan aturan hidup yang bersifat memaksa untuk melindungi kepentingan manusia di dalam masyarakat" (Achmad Ali 2002: 30). Teori perlindungan hukum berhubungan dengan teori hak dan teori kewajiban.

Menurut Satjipto Rahardjo, hak adalah kekuasaaan yang diberikan oleh hukum kepada seseorang, dengan maksud untuk melindungi kepentingan seseorang tersebut. Hak tersebut merupakan pengalokasian kekuasaan tertentu kepada seseorang untuk bertindak dalam rangka kepentingan tersebut (Achmad 
Ali 2002: 232). Van Apeldoorn menyatakan "bahwa tiap-tiap hubungan hukum mempunyai dua pihak, pada satu pihak ia merupakan hak dan pada pihak lain ia merupakan kewajiban."

Hak merupakan kewenangan yang diberikan oleh hukum (undang-undang kepada subjek hukum untuk melakukan atau tidak melakukan sesuatu, sedangkan kewajiban merupakan pembebanan yang diberikan oleh hukum (undang-undang) kepada subjek hukum untuk melakukan sesuatu. Hukum berperan memberikan perlindungan bagi subjek hukum yang meliputi hak, kewajiban dan harta kekayaan serta fisik dari subjek hukum. Apabila subjek hukum tidak melaksanakan kewajiban hukum, maka akibatnya adalah dapat dimintakan pertanggungjawaban secara yuridis.

Menurut teori ada 3 (tiga) macam pertanggungjawaban, yaitu pertanggungjawaban berdasarkan kesalahan (fault based liability) yang merupakan pertanggungjawaban yang terkait dengan perilaku subjek. Tanggung jawab berdasarkan wanprestasi yaitu tanggung jawab berdasarkan kontrak (contractual liability). Menurut teori ini apabila dalam sebuah kontrak ada salah satu pihak yang merasa dirugikan maka yang pertama-tama yang harus dilihat adalah isi dari kontrak atau perjanjian atau jaminan yang merupakan bagian dari kontrak, baik tertulis maupun lisan (Inosentius Samsul 2004: 70-71).

Pertanggungjawaban mutlak adalah pertanggungjawaban yang berkaitan dengan perbuatan yang menurut pembuat undang-undang telah membawa efek yang merugikan, jadi adanya hubungan antara perbuatan dan akibat. Prinsip utama dari pertanggungjawaban mutlak ini adalah tidak perlu adanya syarat kelalaian tergugat dan tidak dapat dikaitkan pula dengan adanya wanprestasi (Inosentius Samsul 2004: 109).

Pada jaminan kebendaan si pemilik benda jaminan adalah orang yang berhak atas benda jaminan dengan menunjukkan alas hak untuk kepemilikan benda jaminan dan dalam teori hukum jaminan kebendaan, bahwa apabila benda jaminan dijadikan sebagai objek jaminan kepada kreditor, maka kreditor merupakan kreditor preferen apabila proses jaminan kebendaan telah didaftarkan kepada lembaga pendaftaran (Badan Pertanahan Nasional dalam hal objek 
jaminannya adalah hak-hak atas tanah yang terdaftar) (Kartini Muljadi dan Gunawan Widjaja 2004: 173).

Kreditor pemegang hak jaminan kebendaan memperoleh perlindungan hukum walaupun objek jaminan beralih kepada pihak lain (droit de suit) (J. Satrio 2007: 305). Menurut teori hukum jaminan seorang debitor tidak dibenarkan menyerahkan benda jaminan yang bukan haknya (kecuali terdapat pemberian kuasa) dengan akibat perjanjian jaminan adalah batal demi hukum. Pembatalan perjanjian jaminan kebendaan tersebut tidak dapat merugikan kepentingan hukum kreditor (pemegang hak jaminan) yang beritikad baik.

\section{Konsepsi hak tanggungan}

Hak tanggungan menurut ketentuan Pasal 1 butir 1 Undang-Undang No.4 Tahun 1996 tentang Hak tanggungan Atas Tanah Beserta Benda-Benda Yang Berkaitan Dengan Tanah, adalah (J. Satrio 1997: 65): hak tanggungan atas tanah beserta benda-benda yang berkaitan dengan tanah, yang selanjutnya disebut hak tanggungan, adalah hak jaminan yang dibebankan pada hak atas tanah sebagaimana dimaksud dalam Undang-Undang Nomor 5 Tahun 1960 tentang Peraturan Dasar Pokok-pokok Agraria, berikut atau tidak berikut benda-benda lain yang merupakan satu kesatuan dengan tanah itu, untuk pelunasan utang tertentu, yang memberikan kedudukan yang diutamakan kepada kreditor tertentu terhadap kreditor-kreditor lain.

Angka 4 Penjelasan Umum Undang-Undang Hak tanggungan juga menyatakan pengertian hak tanggungan, yaitu (Salim H.S. 2004: 306): hak tanggungan adalah hak jaminan atas tanah untuk pelunasan utang tertentu, yang memberikan kedudukan diutamakan kepada kreditur tertentu terhadap krediturkreditur lain. Dalam arti, bahwa jika debitur cidera janji, kreditur pemegang hak tanggungan berhak menjual melalui pelelangan umum tanah yang dijadikan jaminan menurut ketentuan perundang-undangan yang bersangkutan, dengan hak mendahului daripada kreditur-kreditur yang lain.

Rumusan tersebut di atas menetapkan bahwa pada dasarnya suatu hak tanggungan adalah suatu bentuk jaminan pelunasan hutang, dengan hak mendahului bagi kreditor pemegang hak tanggungan dengan objek (jaminan)nya 
berupa hak-hak atas tanah yang diatur dalam Undang-Undang No. 5 Tahun 1960 tentang Peraturan Dasar Pokok-Pokok Agraria (Kartini Muljadi dan Gunawan Widjaja 2004: 13). Lahirnya undang-undang tentang hak tanggungan karena adanya perintah dalam Pasal 51 UUPA, yang menyatakan "hak tanggungan yang dapat dibebankan pada hak milik, hak guna usaha dan hak guna bangungan tersebut dalam Pasal 25, Pasal 33 dan Pasal 39 diatur dalam undang-undang” (Salim H.S. 2004: 99).

\section{Subjek dan objek hak tanggungan}

\section{a. Subjek hak tanggungan}

Subjek hak tanggungan diatur dalam Pasal 8 sampai dengan Pasal 9 UUHT, dari kedua pasal tersebut dapat diketahui bahwa yang menjadi subjek dalam hak tanggungan adalah pemberi hak tanggungan dan pemegang hak tanggungan.

1) Pemberi hak tanggungan

Pemberi hak tanggungan adalah adalah orang atau pihak yang men-jaminkan objek hak tanggungan. Pasal 8 UUHT menentukan bahwa pemberi hak tanggungan adalah orang perseorangan atau badan hukum yang mempunyai kewenangan untuk melakukan perbuatan hukum terhadap objek hak tanggungan yang bersangkutan. Pemberi hak tanggungan bisa debitor pemilik hak atas tanah atau orang lain yang bersedia menjamin pelunasan hutang debitor dengan membebankan tanah miliknya (J.Satrio 2007: 308). Pihak yang dapat menjadi subjek hak tanggungan selain warganegara Indonesia, dengan ditetapkannya hak pakai atas tanah negara sebagai salah satu objek hak tanggungan, bagi warga negara asing juga dimungkinkan dapat menjadi subjek hak tanggungan, apabila memenuhi persyaratan-persyaratan antara lain: (a) sudah tinggal di Indonesia dalam waktu tertentu; (b) mempunyai usaha di Indonesia; dan (c) kredit dipergunakan untuk kepentingan pembangunan di wilayah Negara Republik Indonesia (Adrian Sutedi 2010: 39):

2) Pemegang hak tanggungan

Pasal 9 UUHT menetapkan, "pemegang hak tanggungan adalah orang perseorangan atau badan hukum yang berkedudukan sebagai pihak yang 
berpiutang," dengan demikian yang dapat menjadi pemegang hak tanggungan adalah siapapun juga yang berwenang melakukan perbuatan perdata untuk memberikan hutang, yaitu baik badan hukum maupun orang perseorangan warga negara Indonesia maupun orang asing. Dalam hal ini tidak ada kaitannya dengan syarat pemilikan tanah, karena pemegang hak tanggungan memegang jaminan pada asasnya tidak dengan maksud untuk nantinya kalau debitor wanprestasi memiliki persil jaminan (J. Satrio 2007: 309-310), dan yang harus memenuhi syarat pemilikan nantinya adalah pembeli dalam eksekusi.

\section{b. Objek hak tanggungan}

UUPA telah menentukan macam-macam hak atas tanah, tetapi tidak semua hak atas tanah dapat dijadikan jaminan, untuk dapat dijadikan jaminan hutang dengan dibebani hak jaminan atas tanah, suatu objek harus memenuhi beberapa persyaratan, yaitu (Boedi Harsono 2005: 422):

1) dapat dinilai dengan uang, karena hutang yang dijamin berupa uang;

2) mempunyai sifat dapat dipindahtangankan, karena apabila debitor cidera janji benda yang dijadikan jaminan akan dijual;

3) termasuk hak yang didaftar menurut peraturan tentang pendaftaran tanah yang berlaku, karena harus memenuhi syarat publisitas; dan

4) memerlukan penunjukkan khusus oleh suatu undang-undang.

Obyek yang dapat dibebani hak tanggungan diatur dalam Pasal 4 UndangUndang Hak tanggungan, yaitu:

1) hak atas tanah yang dapat dibebani hak tanggungan adalah:

a) hak milik;

b) hak guna usaha;

c) hak guna bangunan.

2) selain hak-hak atas tanah sebagaimana dimaksud pada ayat (1), hak pakai atas tanah negara yang menurut ketentuan yang berlaku wajib didaftar menurut sifatnya dapat dipindahtangankan dapat juga dibebani hak tanggungan;

3) pemberian hak tanggungan pada hak pakai atas tanah hak milik akan diatur lebih lanjut dengan peraturan pemerintah;

4) hak tanggungan juga dapat dibebankan pada hak atas tanah berikut bangunan, 
tanaman, dan hasil karya yang telah ada atau akan ada yang merupakan satu kesatuan dengan tanah tersebut, dan yang merupakan milik pemegang hak atas tanah yang pembebanannya dengan tegas dinyatakan di dalam akta pemberian hak tanggungan yang bersangkutan;

5) apabila bangunan, tanaman dan hasil karya sebagaimana dimaksud pada ayat (4) tidak dimiliki oleh pemegang hak atas tanah, pembebanan kak tanggungan atas benda-benda tersebut hanya dapat dilakukan dengan penandatanganan serta pada akta pemberian hak tanggungan yang bersangkutan oleh pemiliknya atau yang diberi kuasa untuk itu olehnya dengan akta autentik.

Perlu juga diperhatian Pasal 27 UUHT, yang menentukan bahwa ketentuan undang-undang ini berlaku juga terhadap pembebanan hak jaminan atas rumah susun dan hak milik atas satuan rumah susun" (Salim H.S. 2004: 303). Sehubungan dengan yang ditetapkan oleh kedua pasal di atas, maka yang menjadi objek hak tanggungan adalah (Rachmadi Usman 1998: 78-79):

1) hak milik;

2) hak guna usaha;

3) hak guna bangunan;

4) hak pakai atas tanah negara;

5) hak pakai atas tanah milik, yang akan diatur lebih lanjut dengan peraturan pemerintah;

6) rumah susun dan hak milik atas satuan rumah susun, yang didirikan di atas tanah hak pakai atas tanah negara; dan

7) berikut atau tidak berikut bangunan, tanaman, dan hasil karya yang telah ada atau akan ada yang merupakan satu kesatuan dengan tanah tersebut dan merupakan milik pemegang hak atas tanah.

Mengenai hak milik atas tanah, apabila sudah diwakafkan tidak dapat dibebani hak tanggungan, karena menurut sifat dan tujuannya tidak lagi dapat dipindahtangankan, demikian juga tanah-tanah yang dipergunakan untuk keperluan peribadatan dan keperluan suci lainnya walaupun dikuasai dengan hak atas tanah yang dapat dibebani hak tanggungan. Tanah-tanah bersangkutan baru 
boleh dibebani hak tanggungan, apabila tidak lagi dipergunakan untuk keperluan tersebut dan karenanya dapat dipindahtangankan (Boedi Harsono 2005: 423-424).

\section{Pendaftaran hak tanggungan}

Pemberian hak tanggungan yang dituangkan dalam APHT harus diikuti dengan kewajiban pendaftaran dengan cara dibukukan dalam buku tanah di Kantor Pertanahan. Pendaftaran sekaligus menentukan saat lahirnya hak tanggungan, karena pada saat penandatanganan APHT, hak tanggungan masih belum lahir, yang baru lahir hanyalah "janji" untuk memberikan hak tanggungan (Rachmadi Usman 2008: 453). Pendaftaran hak tanggungan merupakan sesuatu yang sangat penting untuk dilakukan, sehubungan dengan munculnya hak tagih preferen dari kreditor, menentukan peringkat kreditor terhadap sesama kreditor preferen dan menentukan posisi kreditor dalam hal ada sita jaminan atas persil jaminan.

Pasal 13 UUHT menentukan cara pendaftaran hak tanggungan, sebagai berikut:

a. Setelah penandatanganan Akta Pemberian Hak Tanggungan dibuat oleh PPAT dilakukan oleh para pihak, PPAT mengirimkan Akta Pemberian Hak Tanggungan yang bersangkutan dan warkah lain yang diperlukan oleh Kantor Pertanahan. Pengirimannya wajib dilakukan oleh PPAT yang bersangkutan selambat-lambatnya 7 (tujuh) hari kerja setelah penandatanganan Akta Pemberian Hak Tanggungan. Adapun berkas yang diperlukan itu meliputi (Salim H.S. 2004: 180):

1) Surat pengantar dari PPAT yang dibuat rangkap dua dan memuat daftar jenis surat-surat yang disampaikan;

2) Surat permohonan pendaftaran hak tanggungan dari penerima hak tanggungan;

3) Fotocopy surat identitas pemberi dan pemegang hak tanggungan;

4) Sertifikat asli hak atas tanah atau hak milik atas satuan rumah susun yang menjadi objek hak tanggungan;

5) Lembar kedua Akta Pemberian Hak Tanggungan; 
6) Salinan Akta Pemberian Hak Tanggungan yang sudah diparaf oleh PPAT yang bersangkutan untuk disahkan sebagai salinan oleh Kepala Kantor Pertanahan untuk pembuatan sertifikat hak tanggungan;

7) Bukti pelunasan biaya pendaftaran hak tanggungan.

b. Pendaftaran hak tanggungan dilakukan oleh Kantor Pertanahan dengan membuatkan buku tanah hak tanggungan dan mencatatnya dalam buku tanah hak atas tanah yang menjadi objek hak tanggungan, serta menyalin catatan tersebut pada sertifikat hak atas tanah yang bersangkutan;

c. Tanggal buku tanah hak tanggungan adalah hari ketujuh setelah penerimaan secara lengkap surat-surat yang diperlukan bagi pendaftarannya dan jika hari ketujuh itu jatuh pada hari libur, buku tanah yang bersangkutan diberi bertanggal hari kerja berikutnya.

Selanjutnya sebagai bukti adanya hak tanggungan, Kantor Pertanahan menerbitkan sertifikat hak tanggungan sesuai dengan peraturan perundangundangan yang berlaku. Pasal 14 ayat (4) UUHT menentukan bahwa sertifikat hak atas tanah yang telah dibubuhi catatan pembebanan hak tanggungan dikembalikan kepada pemegang hak atas tanah yang bersangkutan, tetapi kreditor dapat memperjanjikan lain dalam Akta Pemberian Hak tanggungan, yaitu agar sertifikat hak atas tanah tersebut diserahkan kepada kreditor.

Sertifikat hak tanggungan memuat irah-irah dengan kalimat: "DEMI KEADILAN BERDASARKAN KETUHANAN YANG MAHA ESA”. Pencantuman irah-irah ini dimaksudkan agar sertifikat hak tanggungan mempunyai kekuatan eksekutorial yang sama dengan putusan pengadilan yang telah memperoleh kekuatan hukum tetap, sehingga apabila debitor cidera janji, siap untuk dieksekusi seperti halnya suatu putusan pengadilan yang telah memperoleh kekuatan hukum tetap (Rachmadi Usman 2008: 463).

Setelah sertifikat hak tanggungan diterbitkan oleh Kantor Pertanahan dan sertifikat hak atas tanah dibubuhi catatan pembebanan hak tanggungan, sertifikat hak tanggungan diserahkan oleh Kantor Pertanahan kepada pemegang hak tanggungan. 


\section{Penghapusan dan pencoretan hak tanggungan}

Ada 4 (empat) hal yang menyebabkan hapusnya hak tanggungan, yaitu (Rachmadi Usman 1998: 125):

a. Hapusnya hutang yang dijamin dengan hak tanggungan, bahwa sesuai dengan sifat accessoir dari hak tanggungan, adanya hak tanggungan tergantung pada adanya piutang yang dijamin pelunasannya. Apabila piutang itu hapus karena pelunasan atau sebab-sebab lain, maka dengan sendirinya hak tanggungan yang bersangkutan menjadi hapus juga;

b. Dilepaskannya hak tanggungan oleh pemegang hak tanggungan, bahwa karena hak tanggungan merupakan hak yang diberikan dan dipunyai oleh kreditor berdasarkan perjanjian dan undang-undang maka kreditor berhak untuk menggunakan atau melepaskan hak tersebut, kesemuanya adalah sesuai dengan prinsip suatu hak. Pelepasan ini dilakukan oleh kreditor pemegang hak tanggungan dengan pemberian pernyataan tertulis kepada pemberi hak tanggungan. Apabila terjadi hal demikian, maka kedudukan pemegang hak tanggungan sebagai kreditor preferen berubah menjadi kreditor konkuren;

c. Pembersihan hak tanggungan berdasarkan penetapan peringkat oleh Ketua Pengadilan Negeri, hal ini terjadi karena permohonan pembeli hak atas tanah yang dibebani hak tanggungan tersebut agar hak atas tanah yang dibelinya itu dibersihkan dari beban hak tanggungan;

d. Hapusnya hak atas tanah yang dibebani hak tanggungan, bahwa hapusnya hak atas tanah ini tidak menyebabkan hapusnya hutang yang dijamin pelunasannya oleh debitor, hanya saja kedudukan kreditor akan berubah yang semula adalah kreditor preferen menjadi kreditor konkuren. Ada beberapa kemungkinan yang dapat menyebabkan hak atas tanah yang dibebani hak tanggungan hapus, yaitu:

1) Jangka waktunya berakhir, kecuali hak atas tanah yang dijadikan objek hak tanggungan diperpanjang sebelum berakhir jangka waktunya;

2) Dihentikan sebelum jangka waktunya berakhir, karena suatu syarat batal telah dipenuhi;

3) Dicabut untuk kepentingan umum; 
4) Dilepaskan dengan sukarela oleh pemilik hak atas tanah;

5) Tanahnya musnah.

Setelah hak tanggungan hapus maka Kantor Pertanahan mencoret catatan hak tanggungan tersebut pada buku-tanah hak atas tanah dan sertifikatnya. Permohonan pencoretan harus diajukan oleh pihak yang berkepentingan dengan melampirkan sertifikat hak tanggungan yang telah diberi catatan oleh kreditor atau pernyataan tertulis dari kreditor bahwa hak tanggungan hapus karena piutang ynag dijamin pelunasannya dengan hak tanggungan itu telah lunas, dan apabila permohonan pencoretan timbul dari sengketa yang sedang diperiksa oleh Pengadilan Negeri lain menurut Pasal 22 ayat (6) UUHT, permohonan tersebut harus diajukan kepada Ketua Pengadilan Negeri yang memeriksa perkara yang bersangkutan, setelah perintah Pengadilan Negeri yang dimaksud diperoleh oleh pihak yang berkepentingan, permohonan pencoretan hak tanggungan diajukan kepada Kepala Kantor Pertanahan dengan melampirkan salinan penetapan atau putusan Pengadilan Negeri yang bersangkutan (Rachmadi Usman 2008: 512).

Setelah permohonan pencoretan diajukan oleh pihak yang berkepentingan, Kantor Pertanahan dalam waktu tujuh hari kerja terhitung sejak diterimanya permohonan tersebut harus melakukan pencoretan catatan hak tanggungan menurut cara yang ditentukan dalam peraturan perundang-undangan yang berlaku. Seiring dengan hapusnya hak tanggungan dan telah dilakukannya pencoretan catatan hak tanggungan, menurut ketentuan Pasal 22 ayat (2) UUHT, sertifikat hak tanggungan yang bersangkutan ditarik bersama-sama dengan buku tanah hak tanggungan dinyatakan tidak berlaku lagi oleh Kantor Pertanahan yang bersangkutan.

\section{Perlindungan bagi kreditor yang beritikad baik karena pembatalan hak tanggungan}

\section{a. Bentuk perlindungan hukum}

Terkait dengan daya mengikatnya perjanjian sebagai undang-undang bagi para pihak yang membuatnya (pacta sunt servanda), pada situasi tertentu daya berlakunya dibatasi antara lain dengan itikad baik. Pasal 1338 ayat (3) KUH Perdata menyatakan bahwa: "perjanjian-perjanjian harus dilaksanakan dengan 
itikad baik". Wirjono Prodjodikoro sebagaimana dikutip Agus Yudha Hernoko (2010: 134) memberikan batasan itikad baik dengan istilah "dengan jujur" atau “secara jujur”, sedangkan P. L. Werry sebagaimana dikutip Daeng Naja (2009: 96) memberikan arti itikad baik dalam hukum perjanjian, berarti kedua belah pihak harus berlaku terhadap yang lain berdasarkan kepatutan diantara orangorang yang sopan tanpa tipu daya, tipu muslihat, akal-akalan dan tidak hanya melihat kepentingan diri sendiri, tetapi juga kepentingan orang lain.

Simposium Hukum Perdata Nasional yang diselenggarakan Badan Pembinaan Hukum Nasional (BPHN) mengartikan itikad baik sebagai (Daeng Naja 2009: 141):

1) kejujuran pada waktu membuat kontrak;

2) pada tahap pembuatan ditekankan, apabila kontrak dibuat di hadapan pejabat, para pihak dianggap beritikad baik; dan

3) sebagai kepatutan dalam tahap pelaksanaan, yaitu terkait suatu penilaian baik terhadap perilaku para pihak dalam melaksanakan apa yang telah disepakati dalam kontrak, semata-mata bertujuan untuk mencegah perilaku yang tidak patut dalam pelaksanaan kontrak tersebut.

Itikad baik memegang peranan penting dalam pembuatan kontrak dan merupakan bagian kewajiban hukum dalam pelaksanaan kontrak yang harus dipenuhi,dengan kata lain itikad baik tidak saja berlaku pada tahap pelaksanaan, tetapi juga pada tahap penandatanganan dan tahap sebelum ditutupnya perjanjian (precontractual fase). Bagi masing-masing calon pihak dalam perjanjian terdapat suatu kewajiban untuk memeriksa (onderzoekplicht) dan memberitahukan (medelingsplicht) sebelum menandatangani kontrak atau masing-masing pihak harus mengadakan penyelidikan dalam batas-batas yang wajar terhadap pihak lawan dalam menutup kontrak yang berkaitan dengan itikad baik (Yahman 2011: 75).

Beranjak dari pemahaman mengenai itikad baik, para pihak yang melakukan perjanjian tidak boleh merugikan pihak lain, serta tidak memanfaatkan pihak lain untuk menguntungkan diri sendiri. Dengan demikian perjanjian tidak hanya ditetapkan oleh kata-kata yang dirumuskan oleh para pihak, tetapi hakim dapat 
melakukan intervensi terhadap kebebasan berkontrak para pihak dengan mendasarkan pada asas itikad baik dan menafsirkan isi kontrak di luar kata-kata yang telah tercantum (Agus Yudha Hernoko 2010: 143).

Apabila asas hukum ini dikaitkan dengan pokok pembahasan penulisan, maka asas hukum tersebut merupakan dasar bagi kreditor untuk mendapatkan haknya, dan jika pihak kreditor sudah terbukti beritikad baik dengan menyerahkan sejumlah uang sebagai pinjaman kredit kepada debitor, dan telah melakukan penerimaan jaminan sesuai dengan peraturan yang berlaku, maka kreditor berhak untuk mendapatkan perlindungan hukum atas haknya sebagai kreditor preferen atas objek hak tanggungan yang telah diberikan debitor untuk menjamin hutanghutangnya kepada kreditor.

Perlindungan hukum atas haknya untuk dapat tetap memegang objek jaminan adalah berdasar pada Pasal 1338 ayat (3) KUHPerdata yang menetapkan bahwa semua perjanjian harus dilaksanakan dengan itikad baik dan Pasal 1339 KUHPerdata yang menyatakan bahwa perjanjian tidak hanya mengikat mengenai hal-hal yang secara tegas dinyatakan di dalamnya tetapi juga untuk hal-hal yang menurut sifat perjanjian diharuskan oleh kepatutan, kebiasaan atau undangundang (Agus Yudha Hernoko 2010: 200).

Didasarkan pada perjanjian kredit antara kreditor dan debitor dan UUHT, maka sudah sepatutnya atas suatu objek jaminan yang telah diikat dengan tata cara dan secara formal telah memenuhi persyaratan yang sesuai dengan ketentuan hukum yang berlaku, mengharuskan kreditor sebagai pihak yang berpiutang tetap dilindungi haknya sebagai pemegang hak tanggungan sampai debitor melunasi hutang-hutangnya pada saat yang telah ditentukan sesuai dengan perjanjian kredit. Hakim wajib memperhatikan asas itikad baik dalam setiap putusannya, khususnya mengenai masalah perjanjian penjaminan ini demi tercapainya perlindungan hukum dan keadilan bagi para pihaknya.

\section{b. Upaya kreditor dalam pengembalian hak preferen akibat pembatalan hak tanggungan}

Apabila objek hak tanggungan dibatalkan oleh Pengadilan, maka kreditor dapat memilih cara penyelesaian sebagai berikut: 
1) Melalui jalur non litigasi (out of court settlement), yaitu penyelesaian sengketa melalui proses di luar peradilan (Agus Yudha Hernoko 2010: 307).

Penyelesaian dengan cara ini dapat ditempuh berdasarkan ketentuan UU No.30 Tahun 1999 tentang Alternatif Penyelesaian Sengketa dan Arbitrase, yang dapat berupa Alternatif penyelesaian sengketa (APS) yang diatur dalam Bab II UU No. 30 Tahun 1999 tentang Alternatif Penyelesaian Sengketa dan Arbitrase. Lembaga alternatif penyelesaian sengketa yang dikenal di Indonesia adalah Konsultasi, Negosiasi, Mediasi, Konsiliasi dan Arbitrase (Gatot Supramono 2009: 280-304):

2) Melalui jalur litigasi (in court settlement), yaitu penyelesaian sengketa melalui proses beracara di Pengadilan (Agus Yudha Hernoko 2010: 307)

Hak kreditor yang merasa dirugikan untuk melakukan upaya penegakkan hak-haknya, didasarkan Pasal 1267 KUHPerdata yang menyatakan bahwa: "pihak yang terhadapnya perikatan tidak dipenuhi, dapat memilih, memaksa pihak yang lain untuk memenuhi perjanjian itu jika masih dapat dilakukan atau menuntut pembatalan perjanjian dengan penggantian biaya, kerugian dan bunga" (Yahman 2011: 82-83).

Perjanjian kredit merupakan bukti telah adanya perikatan antara kreditor dan debitor karena itu bila debitor tidak melaksanakan prestasi, dimana dalam penelitian ini prestasi yang dimaksud adalah memberikan jaminan pengganti senilai objek jaminan yang telah dibatalkan Pengadilan maka kreditor dapat menuntut pemenuhan perikatan. Upaya kreditor untuk menuntut prestasi debitor harus didahului dengan memberikan somasi yaitu suatu teguran agar debitor berprestasi. Perikatan yang dibuat menjadi matang untuk ditagih dan lewatnya tenggang waktu yang diberikan dalam somasi karena debitor dalam keadaan lalai dan wanprestasi (J. Satrio 1999: 136). Apabila setelah diberi somasi, debitor tetap tidak melakukan pemenuhan prestasi, maka kreditor dapat menindaklanjutinya dengan mengajukan gugatan ke Pengadilan.

Menurut Jose Rizal (2012), konsultan hukum di Medan, ada dua cara yang dapat dilakukan kreditor sebagai penyelesaian terhadap dibatalkannya objek jaminan yang diberikan debitor oleh Pengadilan, yaitu: 
1) Melalui musyawarah/mufakat, dimana debitor diminta untuk mengganti objek jaminan yang telah dibatalkan oleh pengadilan dengan objek baru yang secara nominal memiliki nilai yang sama seperti yang telah ditentukan dan objek baru tersebut diikat dengan suatu perjanjian jaminan yang sesuai dengan jenis objek yang diberikan, yaitu dapat berupa hak tanggungan, fidusia, hipotik atau gadai.

2) Melalui Peradilan Negara (Pengadilan), hal ini sebaiknya baru dilakukan jika debitor tidak menunjukkan itikad baiknya untuk memenuhi kewajibannya memberikan jaminan sesuai dengan salah satu klausul yang ada dalam perjanjian kredit. Dalam penyelesaian jenis ini, kreditor mengajukan gugatan ke Pengadilan tetapi sebelum mengajukan gugatan kreditor harus memberikan somasi terlebih dahulu kepada debitor. Dalam hal ini gugatan yang sebaiknya diajukan oleh kreditor adalah gugatan untuk membatalkan perjanjian kredit sehingga debitor harus mengembalikan kredit yang telah diterimanya dari kreditor sekaligus dan seketika serta meminta pembayaran atas semua biaya-biaya yang telah dikeluarkan oleh kreditor termasuk pembayaran ganti kerugian akibat hilangnya keuntungan yang diharapkan oleh kreditor.

Gugatan untuk membatalkan perjanjian kredit akan lebih baik bagi kreditor, hal ini karena kredit mengandung resiko maka sesuai penjelasan Pasal 8 UU Perbankan yang menyatakan bahwa sebelum memberikan kredit, salah satu yang harus dinilai oleh bank adalah watak (character) yang dimaksudkan untuk menilai itikad baik dan kejujuran debitor untuk mengembalikan pinjaman (Rachmadi Usman 2003: 246). Dengan tidak dilaksanakannya pemenuhan prestasi oleh debitor setelah kepadanya diberikan somasi menunjukkan tidak adanya itikad baik debitor sehingga apabila perjanjian kredit tetap dilanjutkan maka akan ada kemungkinan dapat menyulitkan bank sebagai kreditor di kemudian hari.

Setelah dibatalkannya perjanjian kredit oleh putusan pengadilan maka debitor wajib membayar lunas kredit yang sebelumnya telah diterimanya dari kreditor beserta semua biaya-biaya, dan mengganti kerugian yang diderita kreditor. Apabila debitor sebagai tergugat enggan melunasi pembayaran sejumlah 
uang yang dihukumkan kepadanya secara sukarela, maka terbuka kewenangan pengadilan untuk menjalankan putusan secara paksa melalui eksekusi, dengan jalan penjualan lelang harta kekayaan debitor di muka umum dan dari hasil penjualan lelang, dibayarkanlah kepada kreditor selaku Penggugat sesuai dengan jumlah yang disebut dalam amar putusan (M.Yahya Harahap 2009: 65).

\section{Simpulan dan Saran}

\section{Simpulan}

Berdasarkan hasil pembahasan sebelumnya, maka hak tanggungan adalah suatu bentuk jaminan pelunasan hutang, dengan hak mendahului bagi kreditor pemegang hak tanggungan dengan objek (jaminan)nya berupa hak-hak atas tanah yang diatur dalam Undang-Undang No. 5 Tahun 1960 tentang Peraturan Dasar Pokok-Pokok Agraria. Berkenaan dengan perlindungan hukum bagi kreditor pemegang hak tanggungan yang beritikad baik dapat dilihat dari Pasal 1341 ayat (2) KUH Perdata yang menyebutkan:"hak-hak yang diperolehnya dengan itikad baik oleh orang-orang pihak ketiga atas barang-barang yang menjadi pokok perbuatan yang batal itu, dilindungi”, dengan demikian pihak yang beritikad baik akan dilindungi haknya dengan cara tidak mencabut hak-haknya dalam perjanjian hak tanggungan.

Perlindungan hukum atas haknya untuk dapat tetap memegang objek jaminan adalah berdasar pada Pasal 1338 ayat (3) KUHPerdata yang menetapkan bahwa semua perjanjian harus dilaksanakan dengan itikad baik dan Pasal 1339 KUHPerdata yang menyatakan bahwa perjanjian tidak hanya mengikat mengenai hal-hal yang secara tegas dinyatakan di dalamnya tetapi juga untuk hal-hal yang menurut sifat perjanjian diharuskan oleh kepatutan, kebiasaan atau undangundang. Karena itu jika didasarkan pada perjanjian kredit antara kreditor dan debitor, dan UUHT maka sudah sepatutnya atas suatu objek jaminan yang telah diikat dengan tata cara dan secara formal telah memenuhi persyaratan yang sesuai dengan ketentuan hukum yang berlaku maka kreditor sebagai pihak yang berpiutang tetap dilindungi haknya sebagai pemegang hak tanggungan sampai 
debitor melunasi hutang-hutangnya pada saat yang telah ditentukan sesuai dengan perjanjian kredit.

\section{Saran}

Asas itikad baik merupakan dasar bagi kreditor untuk mendapatkan haknya, dan jika pihak kreditor sudah terbukti beritikad baik dengan menyerahkan sejumlah uang sebagai pinjaman kredit kepada debitor, dan telah melakukan penerimaan jaminan sesuai dengan peraturan yang berlaku, maka kreditor harus mendapatkan perlindungan hukum atas haknya sebagai kreditor preferen atas objek hak tanggungan yang telah diberikan debitor untuk menjamin hutanghutangnya kepada kreditor. 


\section{DAFTAR PUSTAKA}

\section{Buku:}

Achmad Ali. 2002. Menguak Tabir Hukum. Jakarta: Toko Gunung Agung.

Adrian Sutedi. 2010 Peralihan Hak Atas Tanah dan Pendaftarannya. Jakarta: Sinar Grafika.

Adrian Sutedi. 2010. Hukum Hak Tanggungan. Jakarta: Sinar Grafika.

Agus Yudha Hernoko. 2010. Hukum Perjanjian, Asas Proporsionalitas dalam Kontrak Komersial. Jakarta: Kencana Prenada Media Group.

Bahsan, M. 2007. Hukum Jaminan dan Jaminan Kredit Perbankan Indonesia. Jakarta: RajaGrafindo Persada.

Boedi Harsono. 2005. Hukum Agraria Indonesia, Sejarah Pembentukan Undangundang Pokok Agraria, Isi dan Pelaksanaannya. Jakarta: Djambatan.

Daeng Naja. 2009. Pengantar Hukum Bisnis Indonesia. Yogyakarta: Pustaka Yustisia.

Gatot Supramono. 2009. Perbankan dan Masalah Kredit. Jakarta: Rineka Cipta.

Harahap, M. Yahya. 2009. Ruang Lingkup Permasalahan Eksekusi Bidang Perdata. Jakarta: Sinar Grafika.

Hasanudin Rahman. 1995. Aspek-Aspek Hukum Pemberian Kredit Perbankan di Indonesia. Bandung: Citra Aditya Bakti.

Hermansyah. 2008. Hukum Perbankan Nasional. Jakarta: Kencana Prenada Media Group.

Inosentius Samsul. 2004. Perlindungan Konsumen. Jakarta: Fakultas Hukum Universitas Indonesia.

Kartini Muljadi dan Gunawan Widjaja. 2004. Seri Hukum Harta Kekayaan: Hak Tanggungan. Jakarta: Prenada Media.

Parlindungan, A.P. 1996. Komentar Undang-undang tentang Hak Tanggungan dan Sejarah Terbentuknya. Bandung: Mandar Maju.

Salim H.S. 2004. Perkembangan Hukum Jaminan di Indonesia. Jakarta: RajaGrafindo Persada.

Satrio, J. 1997. Hukum Jaminan, Hak Jaminan Kebendaan Hak Tanggungan. Bandung: Alumni. 1998. Hukum Perikatan, Perikatan pada Umumnya. Bandung: Alumni.

---------. 2007. Hukum Jaminan, Hak Jaminan Kebendaan. Bandung: Citra Aditya Bakti. 
Rachmadi Usman. 1998. Pasal-pasal tentang Hak Tanggungan Atas Tanah. Jakarta: Djambatan.

-. 2003. Aspek-aspek Hukum Perbankan di Indonesia. Jakarta: Gramedia Pustaka Utama.

--------. 2008. Hukum Jaminan Keperdataan. Jakarta: Sinar Grafika.

Try Widiyono. 2009. Agunan Kredit dalam Financial Engineering. Jakarta: Ghalia Indonesia.

Yahman. 2011. Karakteristik Wanprestasi \& Tindak Pidana Penipuan. Jakarta: Prestasi Pustakaraya. 


\section{BIODATA PENULIS}

$\begin{array}{ll}\text { Nama } & : \text { Lilawati Ginting } \\ \text { Pekerjaan } & : \text { Dosen Fakultas Hukum Universitas Muhammadiyah Sumatera } \\ & \text { Utara } \\ \text { Jabatan } & : \text { Asisten Ahli } \\ \text { Nomor HP } & : \text { 081264994242 } \\ \text { E-mail } & : \text { lilawati.ginting@gmail.com } \\ \text { Alamat Kantor } & : \text { Jl. Kapten Muchtar Basri No. 3, Medan }\end{array}$ 